\title{
What do Vocational Teachers, Industries, and Experts View about the Future Learning of Vocational Schools?
}

\author{
Pardjono Pardjono, Wardan Suyanto, Herminato Sofyan, Wagiran Wagiran \\ Universitas Negeri Yogyakarta \\ Yogyakarta, Indonesia \\ pardjono@uny.ac.id
}

\begin{abstract}
This research was the preliminary study of a multi-year designed research. The research aims to explore experienced vocational teachers, industry and vocational education experts for vocational learning. This study used quantitative inquiry approach with questioner or inventory and Focus Group Discussion (FGD) as the method of data collection. The subjects of the study were 18 experienced teachers from 18 schools, 15 industry representatives, and 10 experts. The results showed that most teachers were noticed that vocational school needs to be improved, the need for adjustment with development, and certificate of competence for graduates. The industry's willingness to be more encouraged in improving quality of workers of vocational school graduates is interesting. Experts are more interested in exploring alternative system that is more effective. The three parties agree on the need to increase cooperation with industry for the purpose of internship, curriculum development, and learning improvement which should always be updated in align with technology changes.
\end{abstract}

Keywords-vocational learning, teacher's views, industry's willingness, expert's on vocational learning

\section{INTRODUCTION}

Indonesia has proclaimed to achieve gold generation in 2045 at the $100^{\text {th }}$ of independence. The gold generation is affordable through great efforts and various ways, one of which is through education. With good education, the gold generation, that is the generation of quality in harmony along with the era, will be achieved, so that Indonesia will still survive as able to compete with people in other parts of the world.

The Fourth Industrial Revolution (i4.0) is in sight, the effort to face the challenges of the era should be started, by preparing a workforce with the ability to adapt to progressive development. The characteristic of i4.0 industry is different from today's. The i4.0 industry has been started with the integration of information and communication technology into production process and other fields. The Fourth Industry i4.0 is characterized by genetic development, artificial intelligence, robotics, nanotechnology, 3D printing and biotechnology, to name is just a few, all of which build and strengthen each other. To prevent unfortunate effects of technological change accompanied by talent shortages, and unemployment, educating of today's workers is critical. The World Economic Forum stated that the accelerating pace of technological, demographic and socio-economic disruption is transforming industries and business models, changing the skills that employers need and shortening the shelf-life of employees' existing skill sets in the process [1].

The gold generation is not impossible, because the prediction of Indonesia will be able to become an economically great country has been studied by several futurists, among others, is by Standard Chartered Bank in the UK. The Chartered Bank predicted that Indonesia in 2030 would occupy the rank of 5 world economic powers, below China, USA, India and Brazil. The McKinsey Global Institute Chairman Raoul Oberman said that Indonesia will be the 7th largest economy by 2030, two levels lower than Standard Chartered Bank forecasting. This prediction is not taken for granted that Indonesia as an economic superpower can simply be achieved without hard efforts. Quite the contrary this prediction will be a challenge to achieve by working harder and harder. In this case vocational education has strategic roles to prepare skilled workers. Another term to describe the generation that will be living in this era is the 21 st century generation.

In the international context, vocational education is commonly referred to Technical and Vocational Education and Training (TVET) [2]. TVET is concerned with the acquisition of knowledge and skills for the world of work [3]. Other definition of vocational education is that vocational education involves preparing people for the world of work, that is, preparing them to "make a living" by the nearby and distant societies [4]. Vocational education differs from all other types of institutionalized education at schools and universities in that learning about the process is an indispensable part of professional competence development" [5].

TVET prepares people to earn a living through work. [6]. TVET is also widely seen as having a key role in promoting both economic and socio-economic growth, increasing productivity, empowering citizens and alleviating poverty [7]. In fact, the 21 st competence has become a topic of discussion by experts and academics associated with the competencies that are expected to be important to have the workforce in the future. It has become widely recognized that TVET provision is an important, even growing, part of national education systems and any skills development agenda. At the same time, the capacity of the TVET to adequately prepare skilled workers through the provision of relevant skills development programmed and a high-quality 
of instruction depends largely on the quality of teachers and trainers [8].

Exponential development of technology is very threatening for everyone and for industry and business, and will have an impact on the qualifications and competence of the workforce. Wagiran has defined 10 soft skills for future competencies, including aspects of honesty, work ethic, responsibility, discipline, applying safety principles, initiative and creativity, cooperation, adjustment, selfconfidence, and tolerance [9].

The Organization for Economic Co-operation and Development (OECD) suggests that if vocational education and training are to serve the needs of the 21 st century workers, then, conceptual knowledge and practice performance are urgently achieved through apprenticeship program. In addition, higher order thinking skills, creativity, critical thinking, communication and collaboration, are essential for absorbing knowledge [10].

In Law Number 20 Year 2003 regarding National Education System (Sisdiknas), learning is the process of interaction of learners with educators and learning resources in the learning environment. Further, learning is as a learner process to built competence. Teachers, as facilitator of learning, provide environments, media, and learning resources for learner afford to built their own knowledge, skills, and attitudes, to develop thinking creativity that will improve learner's thinking ability and increase the learning ability. In Government Regulation 19 Year 2005 paragraph (1) of Article 19 the process of learning should be interactive, inspirational, fun, challenging, motivating, and providing sufficient space for initiative, creativity and independence in align with the talents, interests and the development physical and psychological. Through learning, learners are encouraged to acquire knowledge, to mastery skills, and to develop characters, attitudes and selfconfidence. In other words learning is the process of helping students and encouraging them to actively and sustainably learn throughout life.

The development of science and technology has triggered changes in all fields, such as social, economic, and industry and in turn it will have impacts on requirements of the human resources. The requirements of workers for industries will change accordingly in order to keep the production process running for the industry being survive. Changes in requirements of workforce require changes in the model of teaching or strategies to enable students getting competencies which meet future needs. Hager said that "the competence agenda as an attempt to bridge on-and off-the job learning has failed because of assumptions taken over uncritically from formal learning situations" [11], and furthermore he suggested three key ideas in understanding on new vocational learning, e.g. learning is ongoing process, learning is wider than individual learner, and learning is more than simply skills and propositional learning. Process facilitates product, which at the same time also enhances further process and so on. Although learning is more residing in individuals, however, other important learning occurs at the level of team or organizations. Thus, the significant role of the social nature of learning also needs consideration. What we have now is integration between cognitive, connotative, and affective capacities, as well as other abilities and learned capacities such as technical know-how, skills of all kinds and so forth.
Vocational pedagogy is the "science, art, and craft of teaching" [12], meaning that teaching needs science and theories underlying teaching, activities and needs specific talent to achieve that valuable results. However, teachers reluctance to use theory, that teacher do not tend to make use of teaching models when deciding which teaching strategies to use to respond to particular learning objectives [13]. Concerning teachers characteristics for good teaching is facilitated, Widarto, Pardjono, and Noto Widoto identified 8 (eight) characters i.e. teacher as (1) the adaptor, (2) the visionary, (3) the collaborator, (4) the risk taker, (5) the learner, (6) the communicator, (7) the model, and (8) the leader [14].

Learning in vocational education aims to equip learners with various competencies, attitudes, and job skills. Vocational education at the secondary school level provides job training to become skilled and semi-skilled workers. Therefore, learning on vocational education should be designed based on learning theory, experience in practice, conducive atmosphere to learning with pleasure, and meaningful to the mastery of a job, as stated by Clark and Winch that vocational education is confined to preparing young people and adults for working life, a process often regarded as of a rather technical and practical nature. [15].

Learning which is concerned with the achievement of certain competencies is called competency-based learning. Competence for vocational education is adopted from the workforce competence in the company or the world of work. The Ministry of Worker and Transmigration has developed competency standard in many working fields based on industries endorsement and it has been used as guide to develop curriculum for vocational schools. On the other hand, for academic schools, competencies are developed based on the philosophical bases and the nature of subject. This research is aimed to explore what vocational teachers, industries, and experts of vocational education views about vocational learning at the future of vocational education.

\section{METHOD}

\section{A. Approach and Type of Research}

This study was a preliminary research of the Future Learning Model of Vocational Schools. This preliminary study aims to reveal such current as well as future learning for vocational school in facing the very fast-developing technology. This study employed a quantitative approach of research method and use explanatory description of the results.

\section{B. Setting of Research}

This research was conducted in Vocational High Schools (VHS) in Yogyakarta, in some industries located in Yogyakarta and Middle Java. The research was also conducted in some universities at which some experts of vocational education work.

\section{Research Participants}

The VHS teachers were selected from VHS with many different kinds of fields of expertise and there were 18 (eighteen) teachers from 18 fields of expertise who participated in the FGD. 15 (fifteen) staff from some different kinds of industries in Yogyakarta and Middle Java 
were assigned as respondent, and 10 (ten) experts were selected purposefully and interviewed to get their views on the current and the future vocational learning.

\section{Method of Data Collection}

Data were collected through structured questioner in the form of inventory that is a detailed list of VHS graduate competency, teacher competency, and teacher soft skills. Questioners also accommodate respondent's individual views through some open ended questions. The questioner has been sent to teachers and industries a week before FGD was conducted to give more time and thoughts to the respondents in filling out the questioner. For the experts, data collection was conducted through interview. The collected data then were analyzed descriptively to find the future vocational learning characteristics in which the technology change takes place very quickly.

\section{E. Data Analysis Technique}

Quantitative data were then analyzed by using quantitative descriptive analysis which aims to give a realistic figure of what teachers, industries, and experts view about the vocational learning characteristics in the future. The description of the research results is shown in percentage and divided into three groups: teachers', industries', and experts' views on the future vocational learning characteristics.

\section{RESUlT AND DISCUSSION}

\section{A. Result}

The result of research is described into three parts. First, it describes teachers' views on vocational learning; second, it describes industry's views on vocational learning and the willingness to involve in improving quality of VHS graduates; the third is experts' views on the vocational learning.

\section{1) Vocational Learning Based on Teachers'Views.}

According to vocational teachers the ideal learning is shown in Table I. The serial number in column one in the table shows the order of the percentage of the same opinion of the teacher about vocational learning characteristics.

Table I shows teachers views on vocational learning. The highest frequency is that learning needs to improve number of hours for vocational subjects with $38.46 \%$. The second highest frequency is that learning is expected to be align with current development of technology with $23.08 \%$, and the third is that curriculum should be align with the need of world of work with $15.38 \%$. The rest of 8 aspects are at shared frequency with $7.69 \%$. These are the importance of certificate competence for student from the National Agency for Profession Certification (NAPC); foreign language training, communication skills, the need of soft skills (honesty, discipline, work ethic, and cooperation); improvement of teachers' skills in his/her field; required legal umbrella for teachers in disciplining children; and enabling students to create work in the fields; and cooperation with industry need to be improved. FGD with vocational teachers obtained some picture of existing learning conditions in VHS. Most teachers agree that learning hours of non-vocational subject is overvalued, and therefore, widening gap between curriculum and industry needs.

TABLE I. VOCATIONAL LEARNING FOR VHS BASED TEACHERS VIEWS

\begin{tabular}{|l|l|l|}
\hline No & \multicolumn{1}{|c|}{ Teachers' Views } & \multicolumn{1}{|c|}{$\begin{array}{c}\text { Votes } \\
(\%)\end{array}$} \\
\hline 1 & $\begin{array}{l}\text { Vocational learning need to be improved in } \\
\text { order to be ready to work. }\end{array}$ & 38.46 \\
\hline 2 & $\begin{array}{l}\text { Learning should meet working requirements } \\
\text { Curriculum should be aligned with needs of } \\
\text { field. }\end{array}$ & 15.38 \\
\hline 4 & Competency Certificate of NAPC* for students & 7.69 \\
\hline 5 & Need Foreign language competency & 7.69 \\
\hline 6 & Communication skills training & 7.69 \\
\hline 7 & $\begin{array}{l}\text { Need soft skills (honestly, discipline, working } \\
\text { ethic and team work skills }\end{array}$ & 7.69 \\
\hline 8 & Need to improve teacher expertise in his field & 7.69 \\
\hline 9 & $\begin{array}{l}\text { Need legal umbrella for teacher who } \\
\text { disciplining students. }\end{array}$ & 7.69 \\
\hline 10 & Enable student of create work in his/her feeds. & 7.69 \\
\hline 11 & The operation with industry is improved. & 7.69 \\
\hline
\end{tabular}

* NAPC = National Agency of Profession Certification

Learning in VHS today is also not supported by adequate facilities; such an infrastructure does not fulfill the National Education Standards. The policy on the proportion VHS: General High School (GHS) of 70:30 needs to be reviewed, since the policy encourages the growth of new VHS without adequate support of resources and facilities. Increasing opportunity entering VHS is not accompanied by increasing tightness of entry selection. Being professional vocational teachers need practicing subject in appropriate time. Therefore, the government's policy on dual-skilled teachers, in which non-vocational subject teachers trained in certain vocational skills to enable them to teach vocational subject is less precise policy. By this basis, the government's policy on dual-skilled teachers needs to be reviewed because it conflicts with teacher professionalism theories.

\section{2) Industry Views on Vocational Learning}

Based on questioner and open ended questions to the industry representatives, 26 (twenty six) aspects were obtained, as shown in Table II. Technology develops so rapidly that what is taught today will quickly be obsolete and when student finish what have been learned will be less useful. Regarding this situation, some thoughts were promoted by industry representatives as described in Table II.

Table II, numbers in column 1 does not indicate a priority but only shows the grouping of industry opinions that can be grouped into 26 aspects. From the various industry expectations as shown in Table II it can be summarized that the future of vocational learning should be characterized by some aspects. Vocational learning should develop basic skills, strengthen mental and characters, communication skills, leadership, and problem solving skills. In additions, learning for future in vocational school should also develop ethic, and integrity. To support the teaching and learning model as expected that meeting the workplace requirements, adequate facility, well-planned curriculum, and industry collaboration are becoming essential. 
TABLE II. INDUSTRY EXPECTATION ON VOCATIONAL LEANING IN VHS

\begin{tabular}{|l|l|}
\hline No & \multicolumn{1}{|c|}{ Expectation of Industry on VHS Learning } \\
\hline 1 & $\begin{array}{l}\text { Curriculum should be align with current development and basic } \\
\text { skills }\end{array}$ \\
\hline 2 & $\begin{array}{l}\text { Students need competence in management and entrepreneurship } \\
\text { for his/her future career and creating jobs for other or himself. }\end{array}$ \\
\hline 3 & Strengthen in mental and morale \\
\hline 4 & Students needs mentoring \\
\hline 5 & Students need to monitoring his working \\
\hline 6 & Longer in industrial practice is better for student and for industry \\
\hline 7 & $\begin{array}{l}\text { Teachers need to teach students until they understand the } \\
\text { material }\end{array}$ \\
\hline 8 & Visiting industry is needed. \\
\hline 9 & Provide more guest lecturing from industry or alumni \\
\hline 10 & Need adequate facilities and tools \\
\hline 11 & More working practice in the field for skilled when in industry \\
\hline 12 & Give direct and real working experience \\
\hline 13 & $\begin{array}{l}\text { All VHS is expected to become } 4 \text { years VHS program, and } 1 \\
\text { year for industrial apprenticeship }\end{array}$ \\
\hline 14 & $\begin{array}{l}\text { Students need specialized in his field, match with the interest and } \\
\text { meet industry need. }\end{array}$ \\
\hline 15 & $\begin{array}{l}\text { Students need to have communication skills and up dated library } \\
\text { resource collection }\end{array}$ \\
\hline 16 & $\begin{array}{l}\text { To inculcate working ethic, integrity, good working culture, save } \\
\text { culture and effective working. }\end{array}$ \\
\hline 17 & Need collaboration with the world of work \\
\hline 18 & $\begin{array}{l}\text { For good learning quality as well as quantity of facility are } \\
\text { urgent }\end{array}$ \\
\hline 19 & Student needs leadership competence \\
\hline 20 & Students need problem solving exercise \\
\hline 21 & To be more confidence in learning basic skills \\
\hline 22 & $\begin{array}{l}\text { Students need only basic competence since in industry there will } \\
\text { be specific training skills }\end{array}$ \\
\hline 23 & Learning should be more critical \\
\hline 24 & Needs practicing in a real production \\
\hline 25 & The proportion between theories: practice is 40:60. \\
\hline 26 & $\begin{array}{l}\text { Students need practicing in being autonomous, leadership, and } \\
\text { public speaking. }\end{array}$ \\
\hline & \\
\hline
\end{tabular}

According to the industries, vocational learning that merely equips students with vocational skills as commonly conducted is less appropriate. Learning should also provide the provision of mental, morale, leadership, and entrepreneurship skills hoping that graduates will be keeping important role and having strategic positions in his/her career. The interesting opinion is concerning 4-year VHS program. This 4-year vocational program is developed by the Directorate of Vocational High School Management (VHSM) aimed at adapting the areas of expertise operated by VHSs with the rapid development of certain areas of work. It shows on the Table II line 13 that industries prefer 4-year program of VHS with 3 years in school and 1year in industry taking apprenticeship program.

Table III shows some aspects that make industry willing to collaborate with schools. This is surprising because it is not as widely expected by some people that the unwillingness of building collaboration on educational program with schools is commonly coming from industry.

Table III also shows that there are 11 aspects that the industry provides prospect of cooperation with VHS to improve the quality of graduates who meet workplace and industry requirements. Those 11 aspect cover facilitating apprenticeship program, being worker in the industry, sharing knowledge and technology, improving students' competency, conducting collaborative research, visiting industry, providing staff for school and providing scholarship for the talent students.
TABLE III. THE INDUSTRY WILLINGNESS TO SUPPORT SCHOOLS

\begin{tabular}{|l|l|}
\hline No & \multicolumn{1}{|c|}{ Industry Willingness to Support VHS } \\
\hline 1 & $\begin{array}{l}\text { To provide space for apprenticeship program, industrial } \\
\text { attachment, and consultation in industrial system. }\end{array}$ \\
\hline 2 & To give opportunity for VHS graduates to work in his company \\
\hline 3 & To provide time to share knowledge and experience \\
\hline 4 & To give motivation and knowledge to VHS student. \\
\hline 5 & To improve students competence of in industry \\
\hline 6 & Industry ready to train high competence worker \\
\hline 7 & $\begin{array}{l}\text { Industry is ready to collaborate with VHS doing research, } \\
\text { practice, and industry visit. }\end{array}$ \\
\hline 8 & To provide information on technology apply for schools \\
\hline 9 & To provide resources staff for schools \\
\hline 10 & To give feedback, direction, and reviewer for school \\
\hline 11 & To give scholarship for talent students. \\
\hline
\end{tabular}

\section{3) Experts' Views on Vocational Learning}

Data from experts in vocational education have been collected by interview. The interview has been recorded and transcribed for analysis. Seven expert views or opinions on vocational learning are described in Table IV. Row 1 Table 4 is interesting to talk because it is similar to an industry view. Their thinking that VHS three years is inefficient because they argue that to train the competence of the operator, 3 years is considered time consuming. They think it is better to apply multi-exit multi-entry program to prepare workers by adopting training rather than education principle.

TABLE IV. EXPERT VIEWS ON VOCATIONAL LEARNING

\begin{tabular}{|l|l|}
\hline No & \multicolumn{1}{|c|}{ Expert views on Vocational Learning } \\
\hline 1 & $\begin{array}{l}\text { Three year program for vocational school is considered } \\
\text { inefficient, as having competence for only being operator worker. } \\
\text { It seems will be better when multi entry-multi exit system is } \\
\text { implemented. }\end{array}$ \\
\hline 2 & $\begin{array}{l}\text { It needs shared learning program for VHS, polytechnics, and non } \\
\text { formal skills training for more efficient }\end{array}$ \\
\hline 3 & $\begin{array}{l}\text { In addition to learning to cope regular curriculum content, } \\
\text { students need to learn how to learn competence. }\end{array}$ \\
\hline 4 & $\begin{array}{l}\text { Learning should be tailored to global technological, economic, } \\
\text { and employment needs such as ASEAN Economic Community } \\
\text { (AEC) International Quality Framework (IQF) and certification. }\end{array}$ \\
\hline 5 & $\begin{array}{l}\text { Learning for the future will be ICT based and modular, however } \\
\text { learning should adopt domestic theories of education and } \\
\text { learning developed by Indonesian learning theorists. }\end{array}$ \\
\hline 6 & $\begin{array}{l}\text { Vocational teachers should have experience in working in } \\
\text { industry. }\end{array}$ \\
\hline 7 & Vocational teachers should develop entrepreneurship competence \\
\hline
\end{tabular}

The experts thought that VHS, polytechnics, and non formal skills training institution need shared learning program to achieve efficiency. Learning program for certain skills is designed collaboratively in E-learning model to be implemented in each institution. Learning how to learn is one innovative learning strategy needs to be integrated in learning process in vocational school to prepare them to become long life learner.

There are other important issues for experts that learning should be engaged to global nature whether in technology or economically. Curriculum or VHS is also need to refer the International Quality Framework. In addition learning for the future vocational school should be developed in ICT model. However, teachers required to adopt theories developed by Indonesian theorist such as $\mathrm{Ki}$ Hajar Dewantara's theory of learning and education. Nevertheless, learning needs to be directed not only in the national context, but it needs to lead to international standards. 
Vocational learning of VHS has different characteristics from public schools' or GHS, therefore, requiring different strategies. They also conveyed the idea that learning in VHS needs to reformulate and to restructure. At year one learning programs are focused on equipping students with basic skills, attitudes, and work habits. At the following year students learn vocational expertise, and subsequent year students are trained in vocational in their areas of expertise.

Industry is positioned on a key role and is required to achieve high-quality vocational school graduates because they are also the ones who will employ the graduates. So that the industry may start with allocating their corporate social responsibility (CSR) program for vocational schools, offering apprenticeship program for vocational students, or advocating schools in designing training curriculum and instruction and so forth. Integrating ICT technology in learning process is also recommended in this views since in the future ICT mindset and skills will be supporting life whoever has who will be living in the disruptive community.

Mentoring is an important step for students within learning process. The teacher realizes that in addition to basic and vocational skills, students must also be equipped with characters and attitudes. However, administrative demands for teachers are still considered as constraints which might disturb them in giving more attention on student learning.

\section{B. Discussion}

Based on the results of the research, the Presidential Instruction number 9 year 2016 on the revitalization of VHS in order to improve the quality and competitiveness of Indonesian human resources is very timely match in responding to the thoughts, views, or aspirations of teachers, industry, and vocational education experts. Teachers' views and thoughts of vocational teachers who have real experience of being a vocational teacher seem more pragmatic. For them, ideal learning in VHS covers aspects of developing strong vocational skills; competence, curriculum and learning are designed to respond the needs of the workplace demand; developing characters or soft skills; being competence teacher is importance; and demanding cooperation with industry.

From the participants of teachers, industry and experts there is a common view that the role of industry and the world of work in improving quality of graduates are important. The industry may provide space to vocational students to learn current technology in process of production to give more insight into real world of work. For a long time, the experts believed that the workplace provided the most authentic learning environment for a competent workforce [17] [18] [19].

This is a very valuable input that the policy makers consider these views certainly based on teachers experience and real conditions occurring in VHS. There are some components which need attention in an effort to foster good learning in VHS. Teachers revealed some expectations that learning is concerned with developing competence; fostering discipline, and with building spirit, curiosity, and toughness. Learning materials must be adaptable with the current technology, and the method of learning applied is able to give flexibility to students to be creative so as to provide life skills to learners. Thus learning is basically the learning that improves the ability of students in technical aspects (hard skills) as well as in non-technical skills (soft skills).

The learning process needs to be arranged in a simple system and clear reference with a non-convoluted administrative task for teachers. Teachers should not be burdened with less important administrative tasks to provide more space for teachers to design and perform effective teaching and learning.

The results of interviews with technology and vocational education experts resulted in some formulation of learning in the ideal VHS. Ideal learning will be largely determined by the characteristics of the desired graduates as well as the current portrait of vocational conditions. In harmony with the demands of the 21 st century, the ideal learning in VHS is creative learning that is able to grow and solidify the $21 \mathrm{st}$ century skills that include: critical thinking skills and problem solving, creative and innovative, collaboration, communication and contribution.

From the various industry expectations as shown in Table II it can be inferred that vocational learning is to train students with strong basic skills as well as with qualified vocational skills.

FGD with industry resulting in a learning model, i.e. learning that able to instill basic skills or equip such skills, such as management skills and entrepreneurial skills, that might enable VHS graduate to develop themselves in the future. Vocational learning needs adequate facilities in term of quality as well as quantity.

It is known that the number of entrepreneur in Indonesia is low, that is only $3.1 \%$ of the total population. It is a quite low proportion when compared to neighboring countries, such as Malaysia 5\% and Singapore 7\%, China 10\%, and Japan $11 \%$ of the total population [16]. This gives awareness that VHS graduates in the future, not only to work but also to be able to create jobs for himself or for other by equipping them with entrepreneurship.

\section{CONCLUSION}

The results of this study indicate that VHS is still considered an important institution in preparing students' competence. VHS is needed by middle and lower level society and is the biggest part of Indonesian society. Therefore, the government program through Presidential Instruction No. 9 Year 2016 on VHS Revitalization need to get a positive response from stakeholders either listed on attachment or not.

This study also concludes that between schools and industries possibly can help each other. Industry willingness to support VHS is giving new hopes, therefore, formal collaboration framework need to be constructed and learning in workplace will become reality.

The results of this study are also advised to encourage the government of Indonesia to follow up on these findings by issuing policies related to the industrial role in readymade labor preparation. Starting from the industry's willingness to help vocational schools is being pushed by the government to turn into industrial obligations. It is not 
coercion though but an awareness to the industry that the preparation of skilled labor is in essence its obligation.

\section{REFERENCES}

[1] World Economic Forum. The Future of Jobs, Employment, Skills and Workforce Strategy for the Fourth Industrial Revolution, 2016.

[2] http://www.eng.rmutt.ac.th/thanyaburi-statement-to-supportinternational-collaborations-in-vocational-and-technologicaleducation/

[3] Gough, S. Technical and Vocational Education and Learning: An Investment-based Approach. Great Britain: the MPG Books Group, Bodmin and King's Lynn, 2010.

[4] R.M. Thomas. Education from an International Perspective. Encyclopedia of Education and Human Development (pp.611-648). New York: M.E. Sharpe, Inc, 2005.

[5] F. Rauner. Overview: TVET Research. International Handbook of Education for the Changing World of Work (pp.1443-1460). Germany: Springer Science+Business Media B.V.

[6] C. Winch. Vocational education, work and the aims of economic activity, in L. Clarke and C. Winch, Vocational Education: International approaches, developments and systems. New York, Routledge, 2007, (pp. 133-135)

[7] Lucas, B. Vocational Pedagogy. Germany: UNESCO- UNEVOC, 2014

[8] Axmann, M., Rhoades, A., and Nordstrum, L. Vocational Teachers and Trainers in a Changing World: The Imperative of High-quality Teacher Training Systems. Geneva: ILO, 2015.

[9] Wagiran. The Importance of Developing Soft Skills in Preparing Vocational High School Graduates. International Conference on VTE
Research and Networking 2008: Nurturing Local VTE Research Efforts: A Response to Global Challenges $7-8$ July 2008 Inna Grand Bali Beach Hotel, Bali, Indonesia.

[10] OECD. Learning for Jobs. Synthesis Report of the OECD Reviews of Vocational Education and Training, 2010.

[11] P. Hager. "Towards a new paradigm of vocational learning", in L. Clarke and C. Winch, Vocational Education: International approaches, developments and systems. New York, Routledge, 2007, (pp. 105-117).

[12] B. Lucas., E. Spencer, G. Claxton. How to teach vocational education: A theory of vocational pedagogy. City and Guides Cantre for Skills Development, 2012.

[13] S. Faraday, C. Overton and S. Cooper. Effective teaching and learning in vocational education. London, LSN. 2011.

[14] Widarto, Pardjono, and N. Widodo. Pengembangan model pembelajaran soft skills dan hard skills untuk siswa SMK. Cakrawala Pendidikan 3, Th. XXXI, pp. 409-423.

[15] L. Clarke and C. Winch. Vocational education: International approaches, developments and systems. New York, Routledge, 2007.

[16] http://www.depkop.go.id/content/read/ratio-wirausaha-indonesianaik-jadi-31-persen/, accessed in Mei 4th, 2018.

[17] S. Billet. Workplace pedagogical practices: Co-participation and learning, British Journal of Educational Studies, 50:4, 2002, pp. 457481.

[18] S. Choy \& B.L. Delahaye. Leadership development: Implementation of an organisation centred curricculum, in S. Billet, C. Harteis \& A. Etelaoelto (eds.), Emerging perspectives of learning at work, Rotterdam, Sence Publishing, 2008, Chapter 10.

[19] P. Hager, Conception of learning and understanding learning at work, Studies in Continuinng Education 26, no. 1, 2004, pp. 3-17 